\title{
ASSIGNMENT OF THE METAL-HISTIDINE LIGANDS FROM THE TRITIUM EXCHANGE RATE OF THE HISTIDINE C-2 PROTONS IN THE CU (II), ZN (II) - SUPEROXIDE DISMUTASE FROM SACCHAROMYCES CEREVISIAE
}

\author{
by \\ JOAN C. DUNBAR and JACK T. JOHANSEN \\ Department of Chemistry, Carlsberg Laboratory \\ Gamle Carlsberg Vej 10, DK-2500 Copenhagen Valby \\ and \\ ANTHONY E. G. CASS and H. ALLEN O. HILL \\ Inorganic Chemistry Laboratory, University of Oxford, \\ South Parks Road, Oxford, England
}

Keywords: Superoxide dismutase, Saccharomyces cerevisiae, histidine, ligands, copper, zinc,
C-2 proton exchange

The metal-histidine ligands in the yeast $\mathrm{Cu}, \mathrm{Zn}$-superoxide dismutase have been assigned on the basis of the differential rate of tritium exchange of the histidine $\mathrm{C}-2$ protons. The zinc ligands have been identified as $\mathrm{His}-71$ and His- 80 while His-46, His- 48 and His-120 appear to be coordinated to the copper. The rate of tritium incorporation into His-63 was inconsistent with the coordination of this residue to copper and was suggestive further of a unique coordination of His-63 to zinc.

Abbreviations: $\mathrm{SOD}=$ superoxide dismutase; $\mathrm{Cu}(\mathrm{II}), \mathrm{Zn}(\mathrm{II})-\mathrm{SOD}=$ native superoxide dismutase; $\mathrm{Cu}(\mathrm{I}), \mathrm{Zn}(\mathrm{II})$ $\mathrm{SOD}=$ derivative in which $\mathrm{Cu}(\mathrm{I})$ replaces $\mathrm{Cu}(\mathrm{II})$ in the native copper binding site; $\mathrm{Zn}$ (II)-SOD = derivative in which the copper site is vacant and zinc is bound in the native zinc site; DE = diethyl aminoethyl; NMR = nuclear magnetic resonance; PMSF = phenylmethyl sulfonyl fluoride; PTH = phenylthiohydantoin; SDS = sodium dodecyl sulphate. 


\section{INTRODUCTION}

Superoxide dismutases are a class of metalloenzymes which catalyse the dismutation of superoxide to $\mathrm{O}_{2}$ and $\mathrm{H}_{2} \mathrm{O}_{2}$. The bovine erythrocyte enzyme has been extensively studied and shown to be a dimer of approximate molecular weight 32,000 (12). The enzyme is comprised of two apparently identical subunits, each of which binds a $\mathrm{Zn}(\mathrm{II})$ and a $\mathrm{Cu}(\mathrm{II})$ atom $(12,29)$. X-ray chrystallography of the bovine enzyme suggests that six of the eight histidine residues in the protein sequence are coordinated to either the copper or the zinc (24). One of the residues, His-61, is considered to act as a bridging ligand between the two metals. Although there is considerable sequence homology between the bovine and the yeast superoxide dismutases, the yeast enzyme contains only six histidines (14). These six conserved residues, however, are those which correspond to the proposed metal ligands in the bovine enzyme. 'H-NMR spectroscopy has revealed substantial structural similarity in the geometry of the active sites of the two enzymes and has further suggested that at least five of the six residues in the yeast enzyme are involved in metal coordination (9).

The C-2 proton of histidine imidazole undergoes exchange with deuterium or tritium at a rate which is intermediate between that of the labile $\mathrm{O}-\mathrm{H}, \mathrm{N}-\mathrm{H}$ and $\mathrm{S}-\mathrm{H}$ protons and the very slowly exchanging $\mathrm{C}-\mathrm{H}$ protons. The exchange reaction of the imidazole $\mathrm{C}-2$ proton is $\mathrm{pH}$ dependent and has been attributed to the formation of a stable ylide intermediate (30). The $\mathrm{pH}$ dependence of the exchange enables determination of the histidine $\mathrm{pKa}(22)$ and the reaction has frequently been used to determine $\mathrm{pKa}$ values of the histidine residues within a number of proteins (16-18, 22, 25, 26).

Recent evidence has suggested that metal coordination to the histidine imidazole decreases the rate of exchange of the $\mathrm{C}-2$ proton $(2,8)$ and NMR resonances have accordingly been assigned to liganded and non-liganded histidines on the basis of their differential rate of deuteration of the C-2 protons (8).

In the current investigation it was attempted to use the differential incorporation of tritium into the histidine residues as a method of distinguishing between the copper and zinc ligands in the yeast superoxide dismutase.

\section{MATERIALS AND METHODS}

\subsection{Materials}

S.aureus (V8) protease was obtained from Miles Laboratories (England). Sephadex gels were from Pharmacia Fine Chemicals (Uppsala, Sweden) and ion-exchange resins from Whatman Biochemicals (England). Tritiated $\mathrm{H}_{2} \mathrm{O}$ $\left(5 \mathrm{Ci} \cdot \mathrm{ml}^{-1}\right)$ was supplied by the Radiochemical Centre (Amersham, England) and Dimilume-30 scintillation fluid was purchased from Packard (Illinois, USA). Spectroscopically pure zinc sulphate and copper chloride were obtained from Johnson Matthey Chemicals (England). DPCCtreated trypsin and 1,10-phenanthroline were from Sigma Chemical Company (St. Louis, USA). All other reagents were analytical grade.

SOD was isolated from $S$. cerevisiae by a simplified procedure (HASEMANN et al. in preparation).

\subsection{Preparation of apo-SOD and $\mathrm{Zn}$ (II)-SOD}

Native SOD (100 mg) was dissolved in $5 \mathrm{ml}$

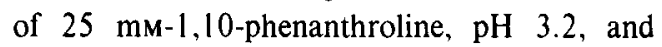
dialysed against $20 \mathrm{vol}$ of the phenanthroline solution for 16 hours at room temperature. The phenanthroline was subsequently removed by gel filtration of the dialysed protein on a column of Sephadex G-50 $(2.5 \times 35 \mathrm{~cm})$ which was equilibrated and eluted with $10 \mathrm{~mm}$-ammonium bicarbonate, $\mathrm{pH} \mathrm{8.0.} \mathrm{The} \mathrm{eluate} \mathrm{was} \mathrm{monitored}$ by the absorbance at $258 \mathrm{~nm}$ and the proteincontaining fractions were pooled and freezedried. This procedure yielded apo-SOD with less than $1 \%$ of the native enzyme activity.

$\mathrm{Zn}(\mathrm{II})-\mathrm{SOD}$ was prepared by reconstitution of the apo-SOD with $\mathrm{ZnSO}_{4}$. The apo-SOD was dissolved in 50 mm-sodium phosphate, $\mathrm{pH} 7.0$, to a final concentration of $25 \mathrm{mg} \cdot \mathrm{ml}^{-1}$. A stoichiometric amount of $\mathrm{ZnSO}_{4}$ was added in a series of aliquots over a period of 1 hour and the sample incubated overnight at room temperature. A small aliquot of the $\mathrm{Zn}$ (II)-SOD was further reconstituted by the addition of an equivalent concentration of $\mathrm{CuCl}_{2}$ and immediately assayed for enzyme activity according to the procedure of MARKLUND and MARKLUND (21). More than $90 \%$ of the native enzyme activity was routinely obtained, suggesting incorporation of the added zinc into the native zinc binding site. 


\subsection{Hydrogen-tritium exchange}

Samples $\left(25 \mathrm{mg} \cdot \mathrm{ml}^{-1}\right)$ of apo-SOD, $\mathrm{Zn}$ (II)SOD and $\mathrm{Cu}, \mathrm{Zn}(\mathrm{II})-\mathrm{SOD}$ in $50 \mathrm{~mm}$-sodium phosphate, $\mathrm{pH} 7.0$, were adjusted to $\mathrm{pH} 8.4$ and lyophilised. The protein was redissolved in ${ }^{3} \mathrm{H}_{2} \mathrm{O}$ $\left(125 \mathrm{mCi} \cdot \mathrm{ml}^{-1}\right)$ to give a final concentration of $25 \mathrm{mg} \cdot \mathrm{ml}^{-1}$. In order to prevent bacterial growth during subsequent prolonged incubation, the protein solutions were filtered through a 0.8 $\mu$ Millipore filter into sterile tubes.

The $\mathrm{Cu}(\mathrm{I}), \mathrm{Zn}$ (II)-SOD was prepared from the solutions of native SOD containing ${ }^{3} \mathrm{H}_{2} \mathrm{O}$. Solid sodium dithionite was added to the $\mathrm{Cu}(\mathrm{II})$, $\mathrm{Zn}$ (II)-SOD until the colour of the protein was completely bleached. After addition of the dithionite the protein solution was readjusted to pH 8.4 with $\mathrm{NaOH}$. Corrections were made, when necessary, for changes in the specific radioactivity of the incubation solution due to the addition of $\mathrm{NaOH}$. The $\mathrm{Cu}(\mathrm{I}), \mathrm{Zn}$ (II)-SOD was maintained in a reduced state by flushing the sample with nitrogen and sealing under vaccuum.

Tritiation of the SOD preparations was carried out at $37^{\circ} \mathrm{C}$ for times as specified in the text. Samples which were subsequently used for isolation of the histidine-containing peptides were routinely incubated for 10 days.

At the completion of the incubation, the tritiated proteins were denatured by acidification to $\mathrm{pH} 1.0$ and passed through a small Sephadex G-25 column eluted with $10 \mathrm{~mm}$-ammonium bicarbonate, $\mathrm{pH}$ 8.5. This procedure enabled removal of the excess tritiated water and also allowed the back-exchange of the labile hydrogens. The eluted protein was then further dialysed against $10 \mathrm{~mm}$-ammonium bicarbonate, $\mathrm{pH} 8.5$, for at least 3 hours at room temperature and until no further changes in specific activity were detected. After dialysis the tritiated protein was lyophilised.

\subsection{Proteolytic digestion of SOD}

The denatured tritiated SOD samples (prepared as in 2.3) were digested with $\mathrm{S}$. aureus protease in $0.1 \mathrm{M}$-ammonium bicarbonate, $\mathrm{pH}$ 8.0 (24). The enzyme:substrate ratio was $1: 30$ and after incubation for 20 hours at room temperature the reaction was terminated by the addition of excess PMSF. The reaction mixture was centrifuged at $30,000 \times \mathrm{g}$ for $15 \mathrm{~min}$ to remove a gelatinous precipitate which appeared during the digestion. The supernatant, containing the soluble peptides, was applied to a Sephadex G-50 superfine column $(2.6 \times 90 \mathrm{~cm})$ and the peptides eluted with $10 \mathrm{~mm}$-ammonium bicarbonate, $\mathrm{pH}$ 8.0. Chromatography was carried out at $4{ }^{\circ} \mathrm{C}$ and the eluted peptides were detected by the absorbance at $230 \mathrm{~nm}$. The composition of the peptides was determined by amino acid analysis.

The precipitate from the protease digestion was washed twice with $\mathrm{H}_{2} \mathrm{O}$, dissolved in $1 \%$ SDS and chromatographed on a column $(2 \times 85$ $\mathrm{cm}$ ) of Sephadex G-50. The column was eluted with $10 \mathrm{~mm}$-sodium phosphate, $\mathrm{pH} 7.0$, containing $0.5 \% \mathrm{SDS}$ and the eluate monitored by absorbance at $230 \mathrm{~nm}$.

Selected peptide fragments from the $S$. aureus protease digestion were lyophilised, redissolved in $0.1 \mathrm{M}$-ammonium bicarbonate, $\mathrm{pH} 8.0$, and incubated with diphenyl carbamide chloride trypsin. The peptides were digested at an enzyme:substrate ratio of $1: 100$ and after 4 hours incubation at room temperature, the reaction was quenched by the addition of PMSF. The resulting peptide mixture was lyophilised, redissolved in a minimal volume of $10 \mathrm{~mm}$ ammonium bicarbonate, $\mathrm{pH} 8.0$, and fractionated on a $0.9 \times 180 \mathrm{~cm}$ column of G-50 (superfine). The column was eluted with $10 \mathrm{~mm}$ ammonium bicarbonate at $4{ }^{\circ} \mathrm{C}$ and at a flow rate of $10 \mathrm{ml} \cdot \mathrm{h}^{-1}$.

\subsection{Amino acid analysis}

The amino acid composition of peptide fragments and histidine concentrations were determined after hydrolysis of peptides in $6 \mathrm{M}$ $\mathrm{HCl}$, in vacuo, for 24 hours at $110^{\circ} \mathrm{C}$. The animo acid analyses were performed on a Durrum D-500 amino acid analyser.

\subsection{Determination of ${ }^{3} \mathrm{H}$-incorporation}

Tritium incorporation into the protein and peptide fragments was determined by suspension of samples $(100 \mu \mathrm{l})$ in $5 \mathrm{ml}$ of Dimilume-30 scintillant and counting in a Packard Tri-carb Liquid Scintillation Spectrometer (Model 2009). 
5

VAL-GLN-ALA-VAL-ALA-VAL-LEU-LYS-GLY-ASP-ALA-GLY-VAL-SER-GLY -VAL-VAL-LYS-PHE-GLU-

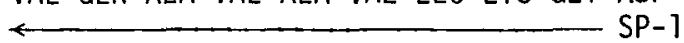

25

35

40

GLN-ALA-SER-GLU-SER-GLU-PRO-THR-THR-VAL-SER-TYR-GLU-ILE-ALA-GLY-ASN-SER-PRO-ASN-

$\longleftrightarrow \mathrm{SP}-2 \longrightarrow \mathrm{SP}-3 \longrightarrow \longleftarrow$ SP-4

50

60

ALA-GLU-ARG-GLY-PHE-HIS-ILE-HIS-GLU-PHE-GLY-ASP-ALA-THR-ASN-GLY-CYS-VAL-SER-ALA-

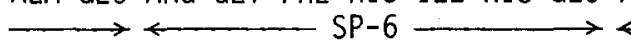

$6570 \quad 75$

GLY-PRO-HIS-PHE-ASN-PRO-PHE-LYS-LYS-THR-HIS-GLY-ALA-PRO-THR-ASP-GLU-VAL-ARG-HIS$\mathrm{SP}-7$

85

90

95

100

VAL-GLY-ASP-MET-GLY-ASN-VAL-LYS-THR-ASP-GLU-ASN-GLY-VAL-ALA-LYS-GLY-SER-PHE-LYS$\mathrm{SP}-8$

105

110

115

120

ASP-SER-LEU-ILE-LYS-LEU-ILE-GLY-PRO-THR-SER-VAL-VAL-GLY-ARG-SER-VAL-VAL-ILE-HISSP-9

$125130 \quad 135 \quad 140$

ALA-GLY-GLN-ASP-ASP-LEU-GLY-LYS-GLY-ASP-THR-GLU-GLU-SER-LEU-LYS-THR-GLY-ASN-ALA-

145

150

GLY-PRO-ARG-PRO-ALA-CYS-GLY-VAL-ILE-GLY-LEU-THR-ASN SP- 10

Figure 1 . The theoretical points of cleavage of the yeast $\mathrm{Cu}(\mathrm{II}), \mathrm{Zn}(\mathrm{II})-\mathrm{SOD}$ by $\mathrm{S}$. aureus protease in $0.1 \mathrm{~m}$ ammonium bicarbonate, $\mathrm{pH} 8.0$.

The expected peptide fragments have been labelled, from the N-terminal of SOD, as the SP-1 to SP-10 peptides.

\section{RESULTS}

\subsection{Fractionation of the histidine-containing peptides}

Determination of the ${ }^{3} \mathrm{H}$-incorporation into the histidine residues necessitated the isolation of the histidines in separate peptide fragments. It appeared from the known amino acid sequence of yeast SOD (15) that digestion with S. aureus protease may facilitate the initial separation of the histidine residues into peptide fragments which could be readily fractionated. The peptide fragments which may be expected from such a digestion and the nomenclature for these peptides are shown in Figure 1.

Incubation of all SOD preparations at $\mathrm{pH} 8.0$ with $\mathrm{S}$. aureus protease resulted in a gelatinous precipitate which when redissolved in SDS and chromatographed in the presence of the detergent yielded an elution profile containing only a single major peak. Amino acid analyses of the peak fractions were consistent with the SP-9 (His-120) peptide. The insolubility of this peptide at $\mathrm{pH} 8.0$ therefore enabled convenient separation of the SP-9 fragment from the remaining histidine containing peptides.

Fractionation of the soluble peptides from the S. aureus protease digestion yielded the elution profile as shown in Figure 2 (a). A small amount of undigested protein together with the protease, eluted near the void volume. Peak 1 was comprised of the SP-7 and SP-10 peptides linked by the disulphide bridge and containing both His-63 and His-71. Subsequent tryptic digestion of the (SP-7 + SP-10) fragment enabled isolation of separate peptides containing His-63 and His-71 (Figure 2 (b)).

Peak 2 from the gel filtration of the $S$. aureus protease peptides (Figure 2 (a)) was heterogeous, although SP-1 appeared to be the predominant peptide. However, since the amino acid analyses 

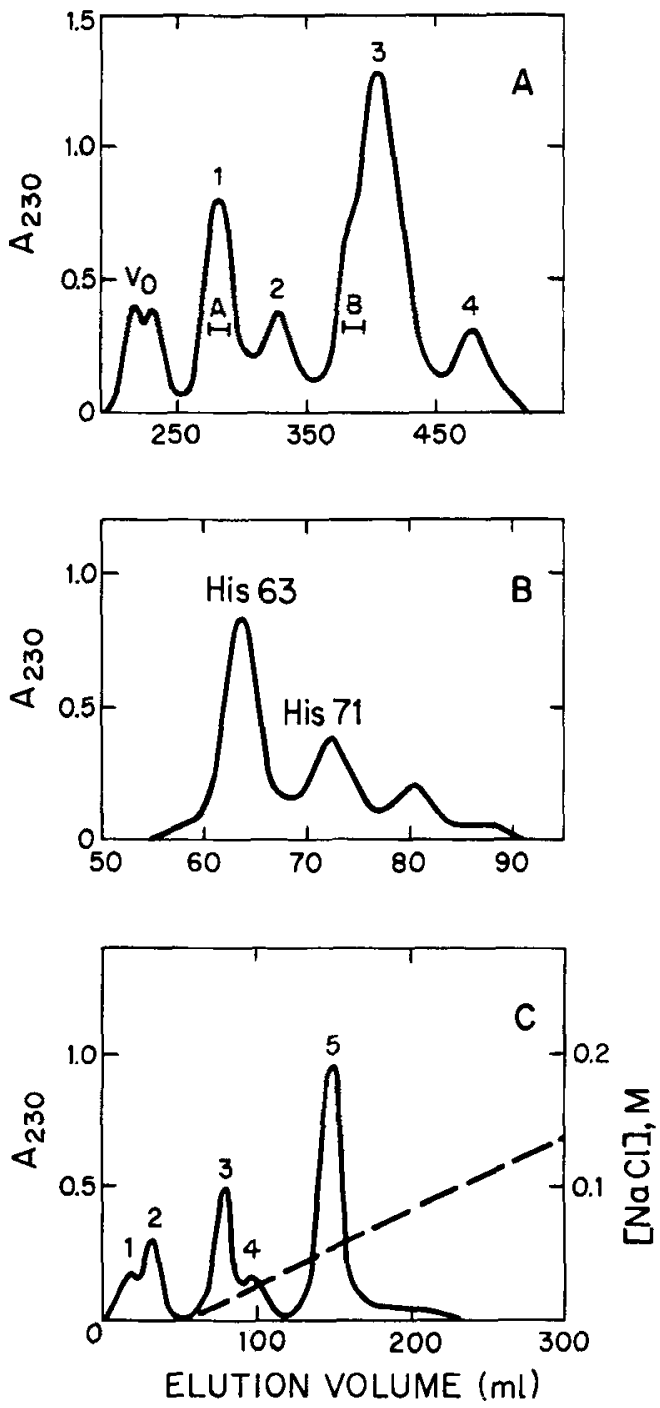

indicated the absence of histidine, no further purification of the peptides was pursued.

The SP-8 (His 80) peptide was eluted in peak 3 , together with the SP-4 and SP-5 peptides. SP-3 also coeluted with these peptides suggesting that the peptide bond between residues 26 and 27 was resistant to hydrolysis. Amino acid analysis of alternate fractions indicated the presence of the histidine-containing peptide in the leading edge of the peak. Fractions were pooled a shown in Figure 2 (a) and the SP-8 peptide further purified by chromatography on DE-52 (Figure 2 (c)).
Figure 2. Fractionation of the histidine-containing peptides from yeast $\mathrm{Cu}(\mathrm{II}), \mathrm{Zn}(\mathrm{II})$-SOD.

(a) Gel filtration of the soluble peptides from $S$. aureus protease digestion of SOD. The peptides were fractionated at $4{ }^{\circ} \mathrm{C}$ on a column $(2.6 \times 90 \mathrm{~cm})$ of Sephadex G-50 superfine which was eluted with 10 mm-ammonium bicarbonate, $\mathrm{pH} 8.0$, at a flow rate of $30 \mathrm{ml} \cdot \mathrm{h}^{-1}$. Peptides were detected by the absorbance at $230 \mathrm{~nm} . V_{0}$ is the void volume of the column. (b) Fractionation of the peptides obtained from tryptic digestion of the (SP-7 + SP-10) fragment (pool A. Figure 2(a)). The peptides were chromatographed on a Sephadex G-50 superfine column $(0.9 \times 180 \mathrm{~cm})$ and eluted at $4^{\circ} \mathrm{C}$ with $10 \mathrm{~mm}$-ammonium bicarbonate, $\mathrm{pH} 8.0$. (c) Purification of the SP-8 peptide. The peptides eluting in pool B (Figure 2(a)) were rechromatographed on a DE-52 column $(1.6 \times 10$ $\mathrm{cm})$. The peptides were eluted initially with $50 \mathrm{ml} 10$ $\mathrm{mm}-\mathrm{Tris}-\mathrm{Cl}, \mathrm{pH} 7.0$ followed by a $300 \mathrm{ml}$ gradient of $0-0.15 \mathrm{M}-\mathrm{NaCl}$ in $10 \mathrm{~mm}-\mathrm{Tris}-\mathrm{Cl}, \mathrm{pH} 7.0$. The SP-8 peptide eluted under peak 3 .

The low molecular weight SP-6 peptide, containing both His-46 and His-48, eluted in peak 4. Only a single residue, lle, interposes these histidines and consequently no attempt was made to isolate these residues in separate peptides.

\subsection{Tritium incorporation into SOD}

There was stable incorporation of tritium into all the SOD preparations during incubation with ${ }^{3} \mathrm{H}_{2} \mathrm{O}$ (Table I). The time course of tritium incorporation is shown in Figure 3. Greatest incorporation occurred in the apo-SOD and after 240 hours incubation the specific radioactivity of the apo-SOD was equivalent to $4.5 \pm 0.2$ moles of tritium per mole of monomer. $\mathrm{Zn}$ coordination to the apo-SOD markedly reduced the rate of tritium incorporation such that the specific radioactivity of the $\mathrm{Zn}$ (II)-SOD, when incubated under the same conditions, represented $40 \%$ that of the apo-SOD. Although the coordination of both $\mathrm{Cu}(\mathrm{II})$ and $\mathrm{Zn}(\mathrm{II})$ further decreased the rate of incorporation, the specific radioactivity of the native SOD was, nonetheless, $20 \%$ that of the apo-SOD.

Comparison of the native and reduced SOD revealed twice the rate of incorporation into the 
Table I

Tritium incorporation into yeast SOD. The protein samples were incubated with ${ }^{3} \mathrm{H}_{2} \mathrm{O}\left(125 \mathrm{mCi} \cdot \mathrm{ml}^{-1}\right)$ at $\mathrm{pH}$ 8.4 for 240 hours at $37^{\circ} \mathrm{C}$. (1) In the presence of $50 \mathrm{~mm}$-sodium phosphate. (2) The protein was titrated to $\mathrm{pH}$ 8.4 with $\mathrm{NaOH}$ and incubated in the absence of phosphate. Specific activities are expressed as mean \pm standard deviation.

\begin{tabular}{|c|c|c|}
\hline \multirow[b]{2}{*}{ SOD } & \multicolumn{2}{|c|}{ Specific activity $\left(\mathrm{cpm} \cdot \mathrm{mg}^{-1}\right) \times 10^{-3}$} \\
\hline & Incubation solution $A^{(1)}$ & Incubation solution $B^{(2)}$ \\
\hline Apo-SOD & $19.1 \pm 2.4$ & \\
\hline $\mathrm{Zn}(\mathrm{II})-\mathrm{SOD}$ & $7.1 \pm 0.8$ & \\
\hline $\mathrm{Cu}(\mathrm{II}), \mathrm{Zn}(\mathrm{II})-\mathrm{SOD}$ & $4.0 \pm 0.5$ & $4.3 \pm 0.4$ \\
\hline $\mathrm{Cu}(\mathrm{I}), \mathrm{Zn}(\mathrm{II})-\mathrm{SOD}$ & $8.1 \pm 0.6$ & $4.2 \pm 0.4$ \\
\hline
\end{tabular}

$\mathrm{Cu}(\mathrm{I}), \mathrm{Zn}$ (II)-SOD. However, the greater rate of incorporation into the reduced SOD appeared to be dependent upon the presence of phosphate in the incubation buffer. Incubation at the same $\mathrm{pH}$ (8.4), but in the absence of phosphate, decreased the tritium incorporation into the $\mathrm{Cu}(\mathrm{I}), \mathrm{Zn}(\mathrm{II})$ SOD while there was no effect on the incorporation into the $\mathrm{Cu}(\mathrm{II}), \mathrm{Zn}(\mathrm{II})-\mathrm{SOD}$. Under the latter incubation conditions, the specific radioactivity of the native and reduced SOD were identical (Table I).

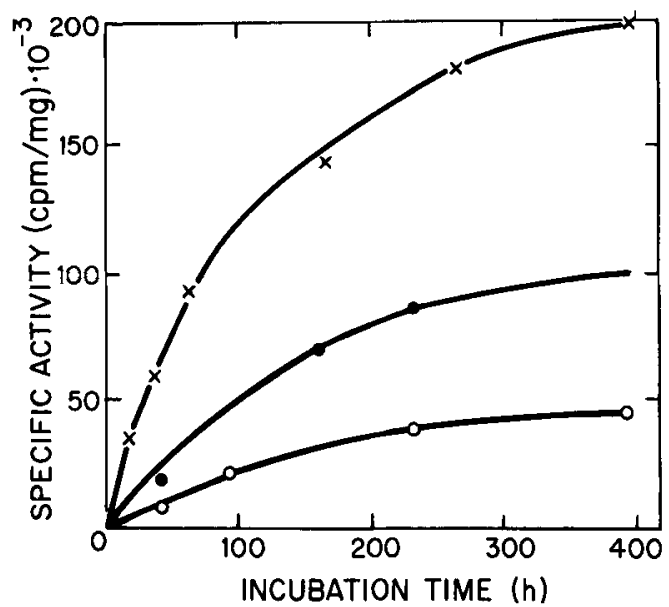

Figure 3. Time course of tritium incorporation into SOD.

The proteins were incubated at $37^{\circ} \mathrm{C}$ in 50 mM-sodium phosphate, $\mathrm{pH} 8.4$, containing 125 $\mathrm{mCi} \cdot \mathrm{ml}^{-1}$ tritium. O-O-O, $\mathrm{Cu}(\mathrm{II}), \mathrm{Zn}(\mathrm{II})-\mathrm{SOD}$; $\bullet-\bullet-\bullet, \quad \mathrm{Cu}(\mathrm{I}), \quad \mathrm{Zn}(\mathrm{II})-\mathrm{SOD}, \mathbf{\square - \square - \mathbf { a }}$, apo-SOD.

\subsection{Incorporation of radioactivity into the histidine residues}

The tritiated native, reduced, $\mathrm{Zn}$ (II)- and apoSOD, when enzymatically digested as described in section 3.1, yielded histidine containing fragments with the specific radioactivities as shown in Table II. Background incorporation, as determined from the SP-4 and SP-5 peptides, was less than $5 \mathrm{cpm}$ per nmole of peptide. All of the histidine residues in the apo-protein incorporated radioactivity and revealed a similar rate of tritium exchange. Reconstitution of the apoprotein with $\mathrm{Zn}$ (II) resulted in a marked decrease in the rate of tritium incorporation by His-71 and His-80. The specific activities were less than $10 \%$ of the corresponding residues in the apoprotein and appear consistent with the coordination of His- 71 and His-80 to the $\mathrm{Zn}$ (II) atom. His-120 in the $\mathrm{Zn}$ (II)-SOD exhibited an incorporation equivalent to that of the nonliganded histidines in the apo-protein. However, the low level of incorporation detected in the native enzyme, implies that His-120 is a copper ligand. The low specific activities of His-46 and His-48 in the native enzyme, and the considerably higher activities in the $\mathrm{Zn}$ (II)-SOD suggest these residues are also involved in copper coordination.

His-63 exhibited unusual incorporation. The specific activity of His-63 in the apo-protein was equivalent to that of the other non-coordinated residues. However, incorporation was also detected, albeit at a lower rate, into the metalloproteins. His- 63 in the $\mathrm{Zn}$ (II)-SOD exhibited a rate of incorporation which, although less than that of the non-coordinated residues, was at least 
TableII

Tritium incorporation into the histidine - containing peptides of yeast SOD. The protein samples were incubated with ${ }^{3} \mathrm{H}_{2} \mathrm{O}\left(125 \mathrm{mCi} \cdot \mathrm{ml}^{-1}\right)$ in $50 \mathrm{~mm}$-sodium phosphate, pH 8.4, for 240 hours at $37^{\circ} \mathrm{C}$. Histidine concentration was determined from amino acid analysis.

\begin{tabular}{rcccc}
\hline $\begin{array}{c}\text { Histidine } \\
\text { Residue }\end{array}$ & Apo-SOD & \multicolumn{2}{c}{ Specific activity $\left(\mathrm{cpm} \cdot \mathrm{nmole} \mathbf{-}^{-1}\right.$ histidine) } \\
& Zn(II)-SOD & Cu(II), Zn(II)-SOD & Cu(I), Zn(II)-SOD \\
\hline 46.48 & 586 & 131 & 17 & 20 \\
63 & 615 & 184 & 98 & 164 \\
71 & 606 & 39 & 24 & 27 \\
80 & 590 & 54 & 37 & 34 \\
120 & 600 & 566 & 32 & 42 \\
\hline
\end{tabular}

three times higher than the tritium incorporation into the $\mathrm{Zn}$ coordinated residues. The specific activity of His-63 in the $\mathrm{Cu}(\mathrm{I}), \mathrm{Zn}(\mathrm{II})$-SOD was very similar to that of the $\mathrm{Zn}$ (II)-SOD, suggesting that the coordination of $\mathrm{Cu}(\mathrm{I})$ to the $\mathrm{Zn}(\mathrm{II})$ SOD has no effect on the rate of tritium incorporation into His-63. In contrast, the tritium incorporation into His-63 in the native $\mathrm{Cu}(\mathrm{II}), \mathrm{Zn}$-SOD was approximately half that of the reduced and $\mathrm{Zn}$ (II)-SOD. However, although the rate of incorporation was comparatively low (approximately 15\% of the non-liganded residues), it was significantly higher than that of the zinc or copper coordinated residues.

\subsection{Incorporation into a non-histidine residue}

The specific radioactivity of the histidine residues accounted for greater than $90 \%$ of the tritium incorporated into the apo and $\mathrm{Zn}$ (II)SOD. However, less than $50 \%$ of the incorporation into copper containing proteins could be attributed to histidine labelling.

Fractionation of the peptides obtained by tryptic digestion of the (SP-7 + SP-10) fragment from the Cu(II), $\mathrm{Zn}$ (II)-SOD is shown in Figure 4. Two peaks of radioactivity were detected and which corresponded to the elution of peptides. However, while peak 1 co-eluted with the His-63 peptide, amino acid analysis of the second peak of radioactivity revealed the absence of histidine. The amino acid composition of peak 2 was consistent with the sequence corresponding to residues 137-143,

$$
\begin{gathered}
140 \\
\text { Thr - Gly - Asn - Ala - Gly - Pro - Arg }
\end{gathered}
$$

and sequence analysis by automatic Edman degradation confirmed the identification.

Attempts were made to identify the labelled amino acid residue. However, the free amino acids isolated after hydrolysis of the peptide in $6 \mathrm{M}-\mathrm{HCl}$ for 18 hours at $110^{\circ} \mathrm{C}$ or the PTH amino acids obtained after Edman degradation were devoid of radioactivity. The lability of the incorporated label under these conditions therefore prevented identification of the reactive amino acid.

It is significant, however, that the tritium incorporation into the peptide was metal specific. Although both the $\mathrm{Cu}(\mathrm{II}), \mathrm{Zn}$ (II)-SOD and the $\mathrm{Cu}(\mathrm{I}), \mathrm{Zn}(\mathrm{II})-\mathrm{SOD}$ incorporated tritium, no radioactivity was detected in either the apo-SOD or $\mathrm{Zn}(\mathrm{II})-\mathrm{SOD}$.

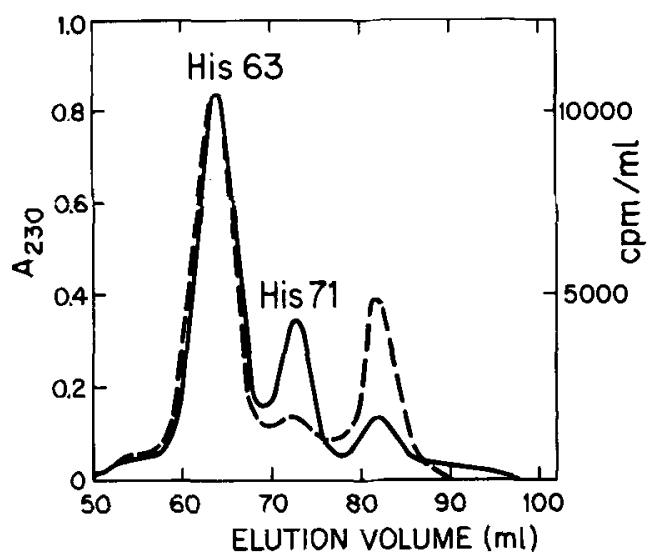

Figure 4. Tritium incorporation into the peptides obtained by tryptic digestion of the (SP-7 + SP-10) fragment from $\mathrm{Cu}(\mathrm{II}), \mathrm{Zn}(\mathrm{II})-\mathrm{SOD}$. $-\mathrm{A}_{230}$; -......, ${ }^{3} \mathrm{H}$-incorporation. 
Table III

Assignment of the copper and zinc ligands in the $\mathrm{Cu}(\mathrm{II}), \mathrm{Zn}$ (II)-SOD.

(1) From differential tritium exchange.

(2) From the X-ray crystal structure (24).

\begin{tabular}{|c|c|c|c|}
\hline \multicolumn{2}{|c|}{ Yeast $^{(1)}$} & \multicolumn{2}{|c|}{ Bovine ${ }^{(2)}$} \\
\hline $\begin{array}{l}\text { Histidine } \\
\text { Residue }\end{array}$ & Ligand & $\begin{array}{l}\text { Histidine } \\
\text { Residue }\end{array}$ & Ligand \\
\hline 46 & $\mathrm{Cu}$ & 44 & $\mathrm{Cu}$ \\
\hline 48 & $\mathrm{Cu}$ & 46 & $\mathrm{Cu}$ \\
\hline 63 & $?$ & 61 & $\mathrm{Cu}+\mathrm{Zn}$ \\
\hline 71 & $\mathrm{Zn}$ & 69 & $\mathrm{Zn}$ \\
\hline 80 & $\mathrm{Zn}$ & 78 & $\mathrm{Zn}$ \\
\hline 120 & $\mathrm{Cu}$ & 118 & $\mathrm{Cu}$ \\
\hline
\end{tabular}

\section{DISCUSSION}

The assignment of the copper and zinc ligands in the yeast SOD, based on the decreased tritium incorporation into the histidine residues upon coordination of copper and zinc to the apo-SOD, are summarized in Table III. Significant inhibition of the incorporation into histidines 71 and 80 in the $\mathrm{Zn}(\mathrm{II})-\mathrm{SOD}$, in comparison to their incorporation in the apo-SOD, prompted the identification of these residues as zinc ligands. Similarly, the low specific activities of His-46, His-48 and His-120 in the native enzyme were interpreted as reflection of their co-ordination to the $\mathrm{Cu}(\mathrm{II})$ ion. The identification of the copper and zinc ligands in the yeast SOD is in good agreement with the assignment of the metal ligands in the bovine SOD based on the X-ray crystal structure (Table III).

Despite the assignment of His-46 and His-48 as copper ligands, the tritium incorporation into these residues in the $\mathrm{Zn}$ (II)-SOD was considerably lower than that of a non-liganded histidine. The decreased incorporation may, however, arise from the location of these residues within the tertiary structure of the protein: X-ray crystallography has revealed that the analogous residues in the bovine SOD reside within that part of the $\beta$ barrel structure which is deeply buried within the protein interior (27). Consequently, His-46 and His- 48 may be less accessible to solvent. Solvent inaccessibility has been suggested as underlying the slow rate of exchange of His-40 in bovine trypsin (18) and KimuRA et al. (16) have recently shown that the magnitude of the second order rate constant in the exchange reaction corresponds to the solvent accessibility of the $\mathrm{C}-2$ proton. Furthermore, since the tritium incorporation into His-46 and His-48 was equivalent to that of a non-liganded residue in the apo-SOD, the low activities in the $\mathrm{Zn}$ (II)SOD may also be indicative of the proposed structural changes $(7,19)$ or decreased flexibility which may occur upon binding of zinc to the apo-SOD. Experiments in which the proteins were not denatured after the incubation with tritiated water revealed that the back exchange of the labile hydrogens in the native and $\mathrm{Zn}$ (II)SOD was considerably slower than that of the apo-SOD.

The rate of histidine C-2 proton exchange therefore appears to be dependent not only upon metal coordination but also on the protein conformation. In addition, structural changes arising from the coordination of metal(s) to the apo-protein may further restrict interpretation of the relative rates of $\mathrm{C}-2$ proton exchange.

It is difficult to deduce the metal co-ordination from the rate of tritium incorporation into His-63. Incomplete reconstitution of the apoprotein with $\mathrm{Zn}(\mathrm{II})$ may be proposed as a possible explanation for the observed incorporation in the $\mathrm{Zn}$ (II)-SOD. However, the low specific activities of His-71 and His-80 in the $\mathrm{Zn}$ (II)-SOD, together with the ability to regenerate full enzyme activity when the $\mathrm{Zn}$ (II)-SOD is further reconstituted with copper, implies not only that zinc has been incorporated into the protein, but that it also is bound in the native zinc binding 
site. It appears, then, that either His-63 is not coordinated to $\mathrm{Zn}$ (II) and that the relatively slow rate of exchange is a consequence of the protein structure or, alternatively, His-63 is a zinc ligand with a unique coordination which allows for the measured rate of exchange of the $\mathrm{C}-2$ proton.

The tritium incorporation into His-63 in the $\mathrm{Cu}(\mathrm{II}), \mathrm{Zn}(\mathrm{II})-\mathrm{SOD}$ was considerably higher than that of the copper liganded residues and apparently inconsistent with a co-ordination of His-63 to copper in the native SOD. However, since the specific radioactivity of $\mathrm{His}-63$ in the native SOD was lower than that in the $\mathrm{Zn}(\mathrm{II})$ SOD, the role of copper in decreasing the rate of exchange may arise not from the coordination of the metal per se, but from changes in the local environment of His-63 upon coordination of copper to the protein.

The conclusion drawn from the current investigation are consistent with those obtained from perturbed angular correlation (PAC) spectroscopy of the Cd(II) substituted SOD (3). The PAC spectra indicated two apparent forms of the $\mathrm{Cd}(\mathrm{II})-\mathrm{SOD}$ and which were considered to represent "flipping " of His- 63 between two coordination positions on the $\mathrm{Cd}(\mathrm{II})$ ion. Such rotation of His-63, with concommitant cleavage and reformation of the ligand bond, may enable the $\mathrm{C}-2$ proton exchange observed in the $\mathrm{Zn}$ (II)SOD in the current experiments. In addition, the PAC studies also failed to detect copper coordination by His- 63 in the $\mathrm{Cu}(\mathrm{II}), \mathrm{Cd}(\mathrm{II})$-SOD. Although there appears to be good correlation between the PAC and tritium exchange data, the coordination of His-63 suggested by these studies is quite distinct from that proposed for the corresponding residue (His-61) in the bovine enzyme. FEE and GABER (11) initially proposed a bridging ligand between the $\mathrm{Cu}(\mathrm{II})$ and $\mathrm{Zn}$ (II) in the bovine SOD. The proposal was based on anion binding studies and gained apparent support when the X-ray crystal structure to $3 \AA$ resolution was presented by RicHARDSON et al. (27). The X-ray data identified His-61 as the proposed bridging ligand and further indicated that the four histidine ligands to the copper were in a slightly distorted square plane, while the ligands to the zinc were in an approximate tetrahedral arrangement. An axially coordinated water molecule to the copper was also inferred. However, despite a number of observations which imply close proximity of the two metals or which have been interpreted in terms of the bridging ligand hypothesis $(1,4,10,13,23,24$, 28 ), there is, as yet, no evidence which has directly shown the existence of His-61 as a bridg. ing ligand.

NMR studies have suggested considerable structural homology between the active sites of the yeast and bovine SOD (9). A number of investigations $(1,10,19,23,24)$ of the bovine enzyme have also indicated similarities in the structure of the $\mathrm{Cu}(\mathrm{I}), \mathrm{X}-\mathrm{SOD}$ and the X-SOD (where $\mathrm{X}=\mathrm{Zn}(\mathrm{II})$, $\mathrm{Co}$ (II) or $\mathrm{Cd}(\mathrm{II})$ ). Accordingly, the tritium exchange experiments suggested similar structures for the yeast $\mathrm{Zn}$ (II)-SOD and $\mathrm{Cu}(\mathrm{I}), \mathrm{Zn}$ (II)-SOD. The consistency of these observations may be a further reflection of the homology between the binding sites of the yeast and bovine SOD. In view of the lack of direct evidence to substantiate the bridging ligand hypothesis, it is tempting to speculate that His-61 in the bovine SOD is not a bridging ligand, but rather is coordinated in a manner similar to that of His-63 in the yeast enzyme. It is of interest, then, that BODEN et al. (4) have noted that the binding constants for azide and cyanide to the $\mathrm{Cu}$ (II) in the bovine SOD are not consistent with the displacement of the axially coordinated water molecule, but were similar to those expected from binding at an equatorial position. Equatorial binding of these anions may be acommodated if there are only three nitrogen ligands, such as we envisage, with the fourth equatorial position occupied by water.

Specific structural changes involving the putative bridging histidine in the bovine SOD are considered to occur during the dismutation of superoxide (10). It has been proposed that important in the catalytic sequence is the cleavage of the copper-nitrogen (His-61) bond, with the uptake of a proton which is subsequently donated to the $\mathrm{Cu}(\mathrm{I})$ bound superoxide. Although the evidence from the current experiments suggest that the analogous His-63 in the yeast SOD is not coordinated to the copper and argues against the bridging imidazole hypothesis, the apparent flexibility of His-63 (3) may, however, be indicative of a critical role for this histidine in the catalytic process.

The rate of tritium incorporation into the reduced SOD was phosphate dependent. Com- 
patible with these observations are the different PAC spectra which have been obtained for the $\mathrm{Cu}(\mathrm{I}), \mathrm{Cd}(\mathrm{II})-\mathrm{SOD}$ in the presence and absence of phosphate (BAUER et al. personal communication). The mechanism by which phosphate induces these apparent structural changes in the reduced SOD is at present unknown. However, NMR studies have also revealed the ability of phosphate to perturb the environment of the metal ligands in the yeast enzyme (CASs, unpublished observations).

In the presence of copper, tritium was incorporated into a specific non-histidine containing peptide fragment. This peptide contains the same arginine (Arg 143) which recently was suggested to be essential for enzyme activity ( 5 , 6). Although the tritium labelled amino acid remains to be identified, it is tempting to speculate that the incorporated label resides in the arginine. Furthermore, the proximity of the side chain of Arg-143 to the active site copper (20) would be consistent with the copper dependence of the tritium incorporation into this peptide. The apparent reactivity of one of the amino acid residues in this peptide warrants investigation and experiments to identify the labelled amino acid are currently in progress.

\section{ACKNOWLEDGEMENTS}

The authors wish to thank Bodil. CoRneliUSSEN for the amino acid analyses and Dr. IB SVENDSEN for sequence determinations. JCD is appreciative of financial support from the Eleanor Sophia Wood Travelling Fellowship and a Danish Government Scolarship.

\section{REFERENCES}

1. Bailey, D. B., P. D. Ellis \& J.-A. Fee: Cadmium-113 nuclear magnetic resonance studies of cadmium-substituted derivates of bovine superoxide dismutase. Biochemistry 19, 591596 (1980)

2. Baldwin, G. S., A. Galdes, H. A. O. Hill, B. E. Smith, S. G. Waley \& E. P. Abraham: Histidine residues as zinc-ligands in $\beta$-lactamase II. Biochem. J. 175, 441-447 (1978)

3. Bauer, R., I. Demeter, V. Hasemann \& J. T. JOHANSEN: Structural properties of the zinc site in $\mathrm{Cu}, \mathrm{Zn}$-superoxide dismutase; pertubed angular correlation of gamma ray spectroscopy on the
$\mathrm{Cu},{ }^{1 / 1} \mathrm{Cd}$-superoxide dismutase derivative. Biochem. Biophys. Res. Commun. 94, 1296-1302 (1980)

4. Boden, N., M. C. Holmes \& P. F. Knowles: Properties of the cupric sites in bovine superox. ide dismutase studied by nuclear-magneticrelaxation measurements. Biochem. J. 177, 303309 (1979)

5. Borders, C. L. \& J. T. Johansen: Essential arginyl residues in $\mathrm{Cu}, \mathrm{Zn}$-superoxide dismutase from Saccharomyces cerevisiae. Carlsberg Res. Commun. 45, 185-194 (1980)

6. Borders, C. L. \& J. T. JohanSEN: Identification of arg-143 as the essential arginyl residue in yeast $\mathrm{Cu}-\mathrm{Zn}$ superoxide dismutase by use of a chromophoric arginine reagent. Submitted for publication.

7. Cass, A. E. A., H. A. O. Hill, J. V. Bannister \& W. H. BanNister: Zinc(II) binding to apobovine erythrocyte superoxide dismutase. Biochem. J. 177, 477-486 (1979)

8. Cass, A. E. G., H. A. O. Hill, J. V. Bannister. W. H. Bannister, V. HaSEmanN \& J. T. JOHANSEN: The exchange of histidine $\mathrm{C} 2$ protons in superoxide dismutases. A novel method for assigning metal ligands in proteins. Biochem. J. $183,127-132$ (1979)

9. Cass, A. E. G., H. A. O. Hill, V. Hasemann \& J. T. JOHANSEN: 'H nuclear magnetic resonance spectroscopy of the yeast copper-zinc superoxide dismutase. Structural homology with the bovine enzyme. Carlsberg Res. Commun. 43, 439-449 (1978)

10. FeE, J. A.: In superoxide and superoxide dismutases (A. M. Michelson, J. M. McCord \& Fridovich, eds.) Academic Press 173-192 (1977)

11. FEE, J. A. \& B. P. GABER: Anion binding to bovine erythrocyte superoxide dismutase. J. Biol. Chem. 247(I), 60-65 (1972)

12. Fridovich, I.: Superoxide dismutases. Ann. Rev. Biochem. 44, 147-159 (1975)

13. Hodgson, E. K. \& I. Fridovich: The interaction of bovine erythrocyte superoxide dismutase with hydrogen peroxide: Inactivation of the enzyme. Biochemistry 14, 5294-5299 (1975)

14. Houmard. J. \& G. R. Drapeau: Staphylococcal protease: A proteolytic enzyme specific for glutamoyl bonds. Proc. Nat. Acad. Sci., USA 69, 3506-3509 (1972)

15. Johansen, J. T., C. Overballe-Petersen, B. Martin, V. Hasemann \& I. Svendsen: The complete amino acid sequence for copper-zinc superoxide dismutase from Saccharomyces cerevisiae. Carlsberg Res. Commun. 44, 201-207 (1979)

16. Kimura, S., H. Matsuo \& K. Narita: Hydro- 
gen-tritium exchange titration of the histidine residues in bovine heart cytochrome $c$ and analysis of their microenvironment. Int. J. Peptide Protein Res. 14, 472-478 (1979)

17. Kimura, S., H. Matsuo \& K. Narita: Hydrogen-tritium exchange titration of histidine residues in ribonuclease $T$, and analysis of their microenvironments. J. Biochem. 86, 301-310 (1979)

18. Krieger, M., R. E. Koeppe \& R. M. Stroud: pH dependence of tritium exchange with the C-2 protons of the histidines in bovine trypsin. Biochemistry 15, 3458-3464 (1976)

19. Lippard, S. J., A. R. Burger, K. Ugurbil, M. W. Pantoliano \& J. S. Valentine: Nuclear magnetic resonance and chemical modification studies of bovine erythrocyte superoxide dismutase: Evidence for zinc-promoted organisation of the active site structure. Biochemistry 16, 11361141 (1977)

20. Malinowski. D. P. \& I. Fridovich: Chemical modification of arginine at the active site of bovine erythrocyte superoxide dismutase. Biochem. 18, 5909-5916 (1979)

21. Markilund, S \& G. Marklund: Involvement of the superoxide anion radical in the autooxidation of pyrogallol and a convenient assay for superoxide dismutase. Eur. J. Biochem. 47. 469474 (1974)

22. Matsuo, H., M. Ohe, F. Sakiyama \& K. Narita: A new approach to the determination of pKa's of histidine residues in proteins. J. Biochem. 72 , 1057-1060 (1974)

23. Mcadam, M. E., E. M. Fielden, F. Lavel.le, L.
Calabrese, D. Cocco \& G. Rotilio: The involvement of the bridging imidazolate in the catalytic mechanism of action of bovine superoxide dismutase. Biochem. J. 107, 271-274 (1977)

24. Moss, T. H. \& J. A. FeE: On the magnetic properties of cobalt substituted bovine superoxide dismutase derivatives. Biochem. Biophys. Res. Commun. 66, 799-808 (1975)

25. Nishikura, K.: Identification of histidine-122 a in human haemoglobin as one of the unknown alkaline Bohr groups by hydrogen-tritium exchange. Biochem J. 173, 651-657 (1978)

26. Ohe, M., H. Matsuo, F. Sakiyama \& K. Narita: Determination of $\mathrm{pKa}$ 's of individual histidine residues in pancreatic ribonuclease by hydrogentritium exchange. J. Biochem. 75, 1197-1200 (1974)

27. Richardon, J. S., K. A. Thomas, B. H. Rubin \& D. C. Richardson: Crystal structure of bovine $\mathrm{Cu}, \mathrm{Zn}$ superoxide dismutase at $3 \AA$ resolution: Chain tracing and metal ligands. Proc. Nat. Acad. Sci. 72, 1349-1353 (1975)

28. Rotilio, G.. L. Cal abrase, B. Mondovi \& W. BI.cMBerg: Electron paramagnetic resonance studies of cobalt-copper bovine superoxide dismutase. J. Biol. Chem. 249, 3157-3160 (1974)

29. Steinman, H. M., V. R. Naik, J. L. Abernathy \& R. L. Hu. I.: Bovine erythrocyte superoxide dismutase. Complete amino acid sequence. J. Biol. Chem. 249, 7326-7338 (1974)

30. Vaughan, J. D., Z. Mugharabi \& E. C. Wu: The kinetics of deuteration of imidazole. J. Organic Chem. 35, 1141-1145 (1970) 